\title{
Water Buffalo Mozzarella Cheese Stored in Polysaccharide-Based Gels: Correlation Between Prolongation of the Shelf-Life and Physicochemical Parameters
}

\author{
P. Laurienzo, ${ }^{*}$ M. Malinconico, ${ }^{*}$ G. Mazzarella, $†$ F. Petitto, $\dagger$ N. Piciocchi, $\dagger$ R. Stefanile, $†$ and M.G. Volpe ${ }^{1}$ \\ *Istituto di Chimica e Tecnologia dei Polimeri, Consiglio Nazionale delle Ricerche, Pozzuoli (NA), Italy \\ †Istituto di Scienze dell'Alimentazione (ISA), Consiglio Nazionale delle Ricerche, 83100 Avellino, Italy
}

\begin{abstract}
An innovative packaging system has been developed, based on natural gels, that has shown the peculiar characteristic to strongly increase the shelf life of water buffalo Mozzarella cheese. To explain the mechanism of action of the gel, measurements of $\mathrm{Ca}$ and $\mathrm{Na}$ in the cheese and in the storage liquid were carried out, together with $\mathrm{pH}$ determination. A correlation has been found between the constant level of $\mathrm{Ca}$ and $\mathrm{pH}$ in the cheese and the prolongation of nutritional characteristics; in fact, both parameters diminish significantly in the absence of gel. At the same time, the weight of the cheese in gel remained constant for as long as $30 \mathrm{~d}$. Confocal laser microscopy gave direct evidence of the persistent physical structure of proteins and lipids of Mozzarella when stored in gel.
\end{abstract}

Key words: Mozzarella cheese, polysaccharide gel

\section{INTRODUCTION}

The real water buffalo Mozzarella (WBM) cheese suffers from limited shelf life. Today, many researchers focus on the development of new methodologies and innovative materials that increase the shelf life of foods, without affecting their quality (so-called mild technologies).

Shelf life of Mozzarella is strictly linked to the type of raw material used (unpasteurized milk) and to the technology of processing. The product obtained from unpasteurized milk and natural whey can be stored and immersed in its mother solution for 3 to $4 \mathrm{~d}$ at a temperature between 4 and $10^{\circ} \mathrm{C}$ with no loss of its characteristics (translucent external skin, white color, soft and elastic curd, peculiar taste of fresh milk, and wildness aroma; Paonessa, 2004). Beyond such period, the external skin peels off, whereas the shred loses

Received June 26, 2007.

Accepted December 3, 2007.

${ }^{1}$ Corresponding author: mgvolpe@isa.cnr.it consistency and becomes buttery after the destruction of the overlapping shells structure obtained during high temperature stretching. Only industrial products, obtained with pasteurized milk and selected starter, can maintain a prolonged shelf life, up to $20 \mathrm{~d}$, but the taste is absolutely unsatisfactory when compared with traditional artisan Mozzarella.

In a previous work (Laurienzo et al., 2006) we reported the results relative to innovative packaging systems, based on natural gels, that have shown the peculiar characteristic to increase the shelf life of the WBM cheese, without adding any chemical substance and without thermal procedures. It is in fact common practice of cheesemakers, particularly for export products, to add preservatives such as citric acid or lactic acid and often to sterilize the milk at high temperatures. These procedures inevitably affect sensorial properties of Mozzarella cheese.

The basis of the innovation is first of all related to the choice of material: mixtures of biodegradable and biocompatible polymers belonging to well-known families of natural polysaccharides, already approved for use in the agro-food industry.

The results published have shown that such innovative gel guarantees a prolonged shelf life up to $20 \mathrm{~d}$ of the traditional Mozzarella with no influence on the values of $\mathrm{pH}$, the microbiological characteristics, the mechanical properties, and the typical taste. Unfortunately, the analysis of the protein fraction from Mozzarella cheese has not explained the differences in mechanical properties between gel-stored WBM cheese and liquid-stored WBM cheese (Laurienzo et al., 2006).

Hence, we speculated that the different behavior could be attributed to the changes in content of $\mathrm{Na}$ and Ca between the 2 types of Mozzarella cheese, following different osmotic exchange of the different storage media (gel and water). In fact, during cheesemaking, the mechanism that regulates curd coagulation is based on an enzymatic modification, from chymosin (enzyme contained in the rennet) of $\kappa$ - $\mathrm{CN}$, that falls in presence of $\mathrm{Ca}$, forming the curd (Vitagliano, 1976); the $\mathrm{pH}$ at 
draining determines the retention of minerals, mainly containing $\mathrm{Ca}$ and $\mathrm{P}$, in the cheese curd (Pastorino et al., 2003). Calcium-neutralizing negative charges of CN molecules increase the affinity of rennet for $\mathrm{CN}$ micelles and the rate of enzymatic reaction; this charge neutralization facilitates protein-to-protein interactions between $\mathrm{CN}$ molecules, which increases the aggregation of renneted micelles (Vitagliano, 1976). The content of $\mathrm{Ca}$ then affects the extent and degree of protein aggregation determining the basic structure and texture of cheese (Lucey et al., 2003; Pastorino et al., 2003). It is generally accepted that $\mathrm{pH}$ and $\mathrm{Ca}$ concentration influence the ability of curd to plasticize in hot water or hot dilute brine (Joshi et al., 2004; Lee et al., 2005; McMahon et al., 2005).

It has been suggested that adding salt promotes $\mathrm{Ca}$ solubilization from paracasein in CN pellets and cheese, thus displacing $\mathrm{Ca}$ from the protein matrix and into the serum (Pastorino et al., 2003). After permanence in pickle, where salt concentration is 10 to $18 \% \mathrm{NaCl}$, WBM cheese has a greater salt content in peripheral zones, whereas down to some millimeters from the surface, the content of $\mathrm{NaCl}$ is almost null. In preservation liquid, salt concentration tends to become homogeneous in all the Mozzarella cheese; in fact, from external zones of Mozzarella cheese, salt migrates toward the inner layers, replacing itself with $\mathrm{Ca} ; \mathrm{NaCl}$ promotes microstructural swelling, a concomitant increase in waterholding capacity, and the solubilization of intact $\mathrm{CN}$ from the paracasein matrix (Guo et al., 1997). Unfortunately, little information is available on the effects of $\mathrm{pH}$ and $\mathrm{Ca}$ content, and of their interaction, during storage of Mozzarella cheese in preservation liquid.

The aim of this work was to verify the effectiveness of our innovative packaging system to avoid large changes of content of $\mathrm{Na}$ and $\mathrm{Ca}$ in Mozzarella cheese during preservation until $30 \mathrm{~d}$, compared with the Mozzarella cheese in preservation liquid, to explain the persistence of mechanical and nutritional properties of Mozzarella in gel.

\section{MATERIALS AND METHODS}

\section{Materials}

Nitric acid was obtained from Carlo Erba Reagenti, Rodano (Mi), Italy. Water TraceSelectUltra (for trace analysis) was obtained from Fluka, Sigma-Aldrich Chemie GmbH, Buchs, Switzerland. Sodium and $\mathrm{Ca}$ (standard for atomic absorption), concentration $=1 \mathrm{mg} /$ $\mathrm{mL}$, in diluted hydrochloric acid, were obtained from Carlo Erba Reagenti. Rhodamine B fluorescent dye was obtained from Sigma Chemical Co. (St. Louis, MO). Lipid-soluble Nile Blue fluorescent dye was obtained from Sigma Chemical Co.

\section{Samples Packaging}

The WBM cheese samples used in this study were acquired at local supermarkets. Gel for sample conservation was prepared as described in Laurienzo et al. (2006). The samples in gel and the samples in preservation liquid were stored at $4^{\circ} \mathrm{C}$ and analyzed at different storage times. Experiments were run in triplicates, and the measurements were performed according to this time schedule (d): $0,2,4,8,10,15,20,30$.

\section{pH Measurements}

The $\mathrm{pH}$ determinations were carried out by a CRISON $507 \mathrm{pH}$ meter equipped with type 52-00 electrodes and a type 52-32 electrode for penetration analysis. The analysis was carried out on the preservation liquid, on the cheese stored in it, and on the cheese stored in the gel; $\mathrm{pH}$ of the gel was neutral.

\section{Samples Mineralization}

Cheese samples $(5 \pm 0.1 \mathrm{~g})$, stored in gel and preservation liquid, were placed in a drying oven at $105^{\circ} \mathrm{C}$ for $5 \mathrm{~h}$. Samples were weighed for determination of the tenor in DM and carbonized on the Bunsen flame. Successively, samples were placed in a furnace at $550^{\circ} \mathrm{C}$ for $10 \mathrm{~h}$ until they turned to white ash. Following, they were suspended in $3 \mathrm{~mL}$ of nitric acid 10\% (Carlo Erba Reagenti), taken to a final volume of $25 \mathrm{~mL}$ with Water Tracepur Fluka (Sigma-Aldrich Chemie $\mathrm{GmbH}$ ) and filtered with a syringe filter SFCA membrane $0.45 \mu \mathrm{m}$ (Millex, Millipore, Bedford, MA), for inorganic trace analysis.

Preservation liquid was filtered with syringe filter SFCA membrane $0.45 \mu \mathrm{m}$ and analyzed.

\section{Samples Analysis}

A spectrophotometer Varian AA-200 (Mulgrave, Victoria, Australia) was used for this work with a flame burner for analysis of $\mathrm{Na}$ and $\mathrm{Ca}$ concentration.

The hollow cathode metal lamp was used at opportune wavelength: for Ca determination, the lamp was set at $422.7 \mathrm{~nm}$, whereas for Na determination, a value of emission of $589.0 \mathrm{~nm}$ was set.

Metal atomic absorption standard solutions with $\mathrm{Na}$ and $\mathrm{Ca}$ as solutes (Carlo Erba Reagenti, concentration = $1 \mathrm{mg} / \mathrm{mL}$, in diluted hydrochloric acid) were used to prepare the working standard for the programmable sample dispenser. The final concentration of nitric acid in all the solutions was $0.5 \% \mathrm{vol} / \mathrm{vol}$.

A new rational calibration procedure was selected on the Spectrophotometer AA to assess the amount of 
Table 1. The $\mathrm{pH}$ value of preservation liquid of water buffalo Mozzarella cheese in preservation liquid and in gel at different times

\begin{tabular}{lccc}
\hline $\begin{array}{l}\text { Conservation } \\
\text { time }\end{array}$ & LP $^{1}$ & WBLP $^{2}$ & WBgel $^{3}$ \\
\hline 0 & 4.28 & 5.25 & 5.25 \\
2 & 4.53 & 5.15 & 5.28 \\
4 & 4.70 & 5.05 & 5.30 \\
6 & 3.87 & 5.12 & 5.27 \\
8 & 4.34 & 5.03 & 5.31 \\
10 & 4.29 & 5.01 & 5.37 \\
15 & 5.03 & 5.05 & 5.47 \\
20 & 5.54 & 4.99 & 5.50 \\
30 & 4.94 & 4.89 & 5.68 \\
\hline${ }^{1} \mathrm{LP}=$ preservation liquid. & & \\
${ }^{2} \mathrm{WBLP}=$ water buffalo Mozzarella cheese in preservation liquid. \\
${ }^{3} \mathrm{WBgel}=$ water buffalo Mozzarella cheese in gel.
\end{tabular}

metal in the samples. Peak height-measurement mode was used.

\section{Weight Measurements}

The samples were weighed at time 0 and during the preservation, according to the protocol.

\section{Confocal Laser Scanning Microscopy}

Mozzarella from 3 trials (fresh, $21 \mathrm{~d}$ in gel, $21 \mathrm{~d}$ in preservation liquid) were examined by confocal laser scanning microscopy.

Sections of Mozzarella, approximately $10 \times 10 \times 2$ $\mathrm{mm}$ thick, were cut with a razor blade $\left(\right.$ at $\left.4^{\circ} \mathrm{C}\right)$, placed on a microscope slide, and stained by immersion for 2 min in a $0.1 \%$ solution of water-soluble Rhodamine B fluorescent dye (Sigma Chemical Co.). Excess dye was washed off with distilled water. Lipid-soluble Nile Blue fluorescent dye (Sigma Chemical Co.) was then directly applied in solid form to the surface of the Mozzarella. Both of these dyes were used concurrently to observe the fat and aqueous phases of the Mozzarella. The sample preparation procedure was performed over ice to keep the temperature low and minimize fat globule distortion. The Mozzarella samples were observed using confocal laser scanning microscopy (Leica, Heidelberg, Germany), with an argon-HeNe laser in dualbeam fluorescent mode and excitation wavelengths of 647 and $568 \mathrm{~nm}$ for the fat and aqueous phase, respectively. The fat globule size in the Mozzarella structure was determined from the microscope images using Image Tool for Windows NT version 2.0

\section{RESULTS AND DISCUSSION}

The values of $\mathrm{pH}$ are reported in Table 1 . The $\mathrm{pH}$ of the preservation liquid changes from acid value to a more alkaline value, even though not very monotonically. The $\mathrm{pH}$ of Mozzarella cheese, stored in preservation liquid, changes from a value of $5.25(\mathrm{~d} 0)$ to a value of 4.89 (d 30), whereas $\mathrm{pH}$ of gel-stored Mozzarella cheese showed regular variations, changing from 5.25 (d 0) to 5.68 (d 30).

In Figures 1, 2, and 3 are reported the values of the content of $\mathrm{Ca}$ and $\mathrm{Na}$ in Mozzarella cheese and its preservation liquid. It is evident that there is a migration of Ca from Mozzarella cheese to preservation liquid and a migration of $\mathrm{Na}$ from preservation liquid to Mozzarella cheese. These drastic changes, together with the observed change of value of $\mathrm{pH}$ could be responsible for changes in rheological characteristics of Mozzarella

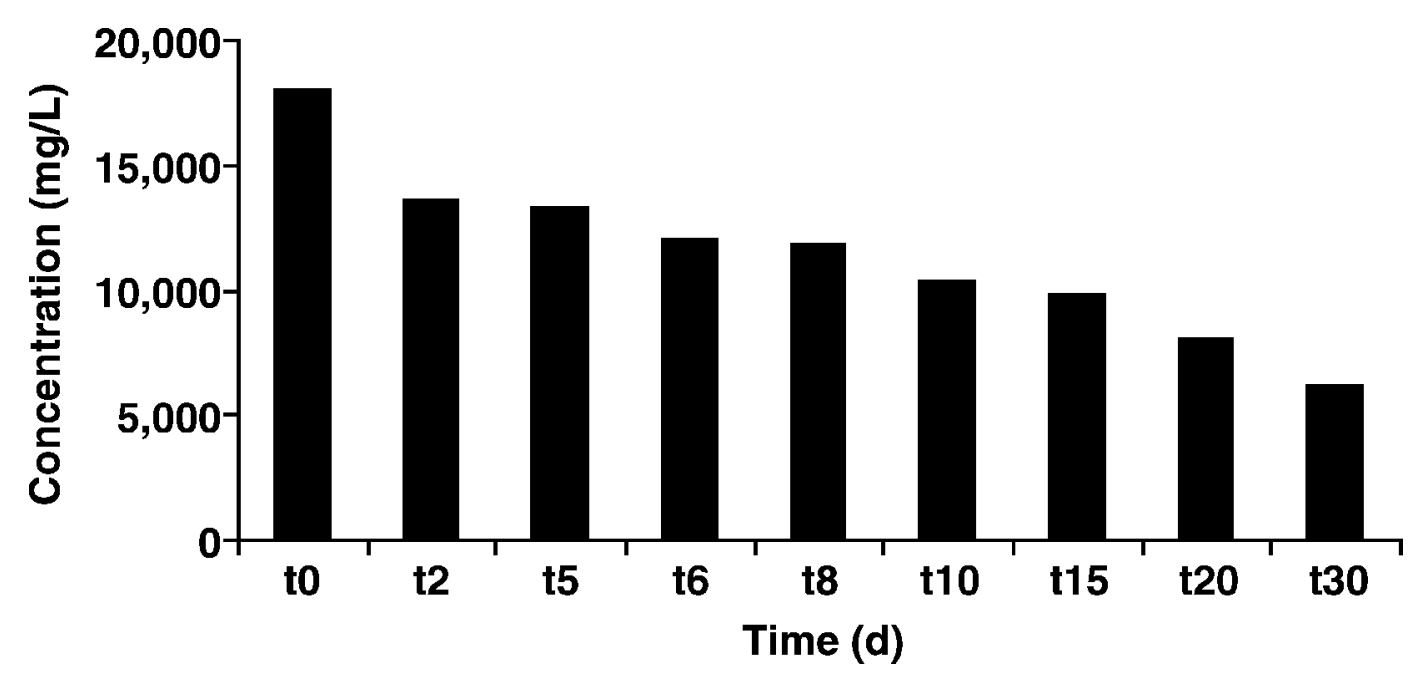

Figure 1. Sodium concentration in preservation liquid $(\mathrm{mg} / \mathrm{L})$ relative to conservation days. Standard deviation is less than $0.2 \%$. 


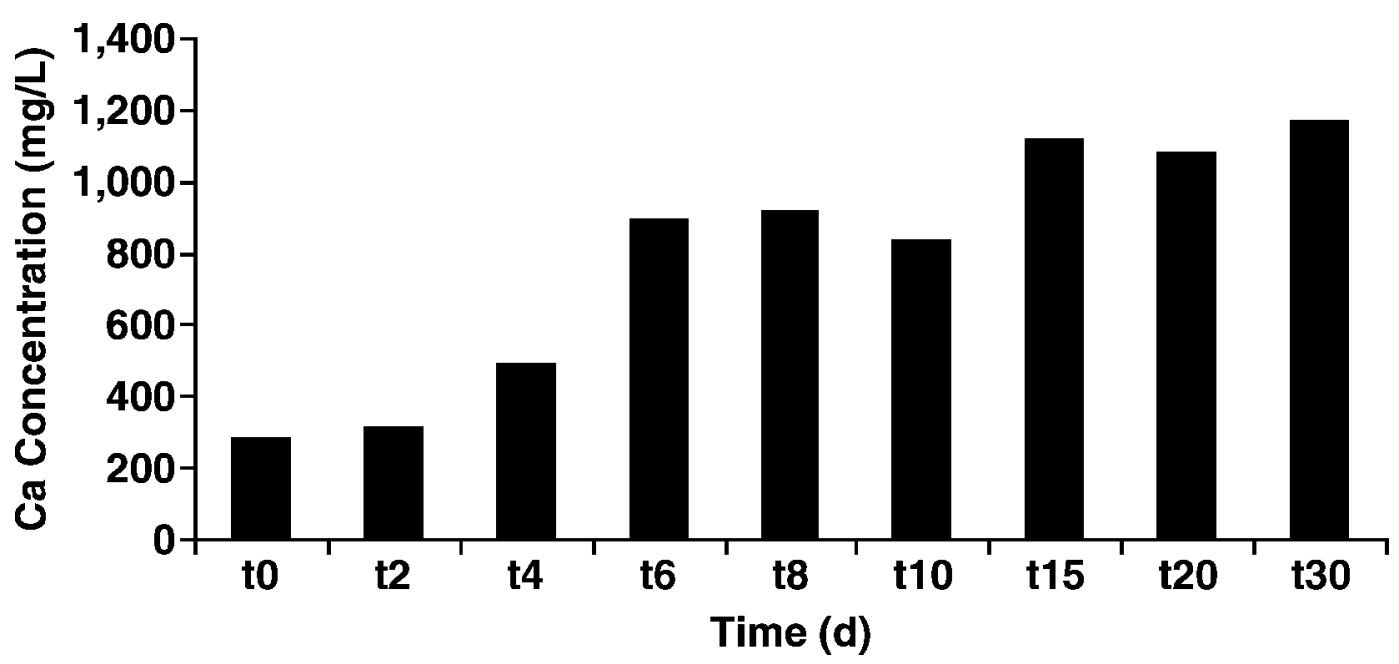

Figure 2. Calcium concentration in preservation liquid $(\mathrm{mg} / \mathrm{L})$ relative to conservation days. Standard deviation is less than $0.2 \%$.

cheese; in fact, as reported in literature, stretchability of Mozzarella is influenced by $\mathrm{pH}$ and $\mathrm{Ca}$ content (Kimura et al., 1992; Guinee et al., 2002; Hassan et al., $2004)$, whereas an increase in the value of $\mathrm{NaCl}$ promotes microstructural hydrating and swelling of the protein matrix (Guo et al., 1997; Pastorino et al., 2003). In particular, a $\mathrm{pH}$ reduction increases the ratio between soluble Ca over colloidal $\mathrm{Ca}$, which in turn would increase the degree of hydration of CN (Sood et al., 1979) and reduce its aggregation state, which then increases the susceptibility of $\mathrm{CN}$ to hydrolysis (Feeney et al., 2002).

In Figure 4 are reported the values of the content of $\mathrm{Ca}$ and $\mathrm{Na}$ in Mozzarella cheese stored in gel up to 30 $\mathrm{d}$. As for the $\mathrm{pH}$ (Table 1), changes in $\mathrm{Ca}$ and $\mathrm{Na}$ in these samples are strongly reduced. There are small variations of the 2 elements, due probably to the intrinsic variability of artisan samples; in fact, the changes are in a range of 4,000 to $5,000 \mathrm{mg} / \mathrm{kg}$, whereas, for Mozzarella cheese stored in preservation liquid, these variations are drastic, as shown in Figures 5 and 6.

Stability of $\mathrm{pH}$ and of the content of $\mathrm{Na}$ and $\mathrm{Ca}$ in the gel-stored WBM cheese could explain its almost constant rheological and mechanical characteristics.

As an additional proof of the importance of regulation of the salt exchange, gel-stored and liquid-stored WBM cheeses have been weighed in time, and the results are reported in Table 2; for WBM stored in its preservation liquid, there is an increase in weight from 20 to $35 \%$ of the original weight. These differences in the weight could be attributed to the osmotic pressure change that determines the preservation liquid to enter the cheese.

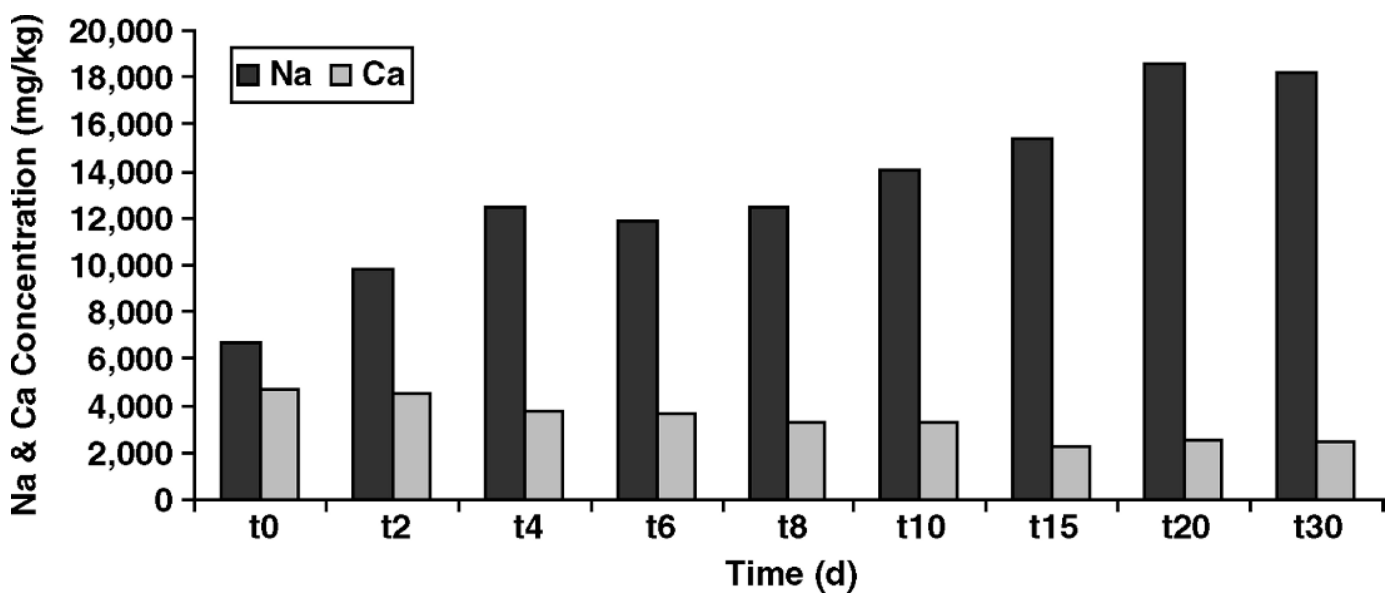

Figure 3. Sodium and Ca concentration in water buffalo cheese $(\mathrm{mg} / \mathrm{kg})$ relative to conservation days. Standard deviation is less than $0.2 \%$. 


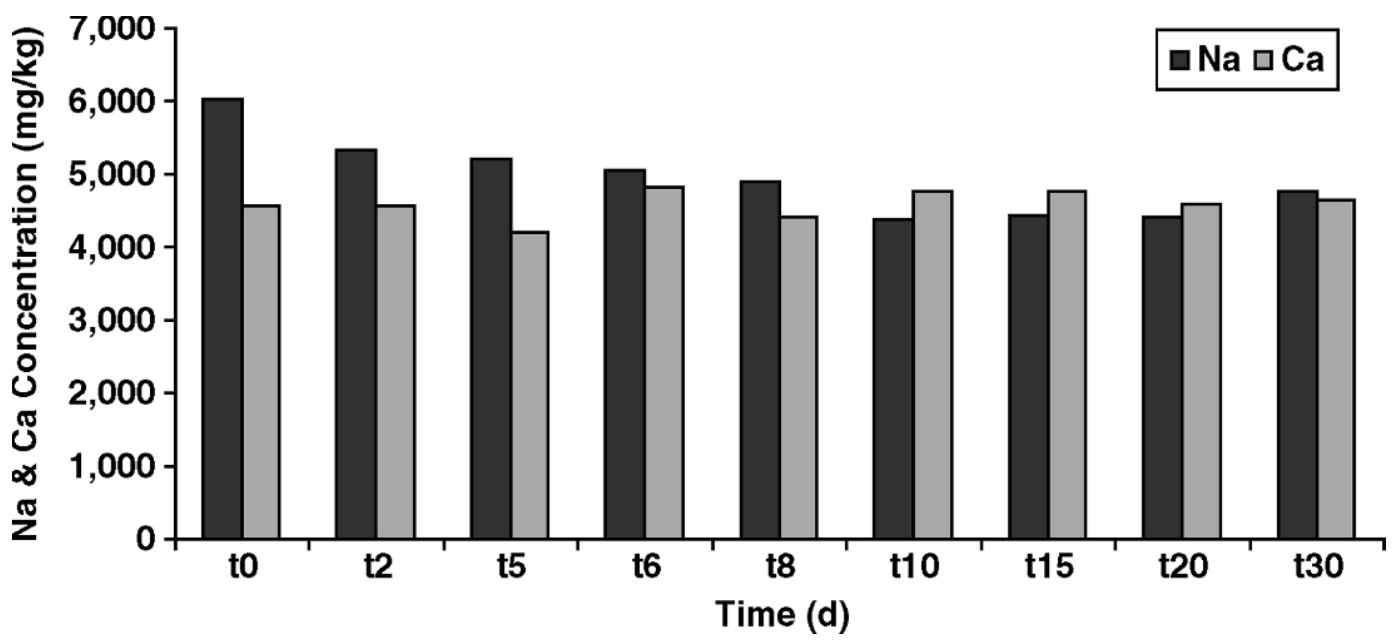

Figure 4. Calcium and Na concentration in water buffalo cheese in gel $(\mathrm{mg} / \mathrm{kg})$ relative to conservation days. Standard deviation is less than $0.2 \%$

For the WBM cheese in polysaccharide gel, this variation ranges from 0.32 to $1.78 \%$, as a consequence of the capacity of gel to release on demand a little amount of water that is absorbed by cheese and helps to preserve an optimal degree of humidity .

The microscopic structure of Mozzarella, in particular the protein network, greatly influences physical properties and sensory attributes. Confocal laser scanning microscopy is considered a powerful tool to study the microstructure of Mozzarella, because the laser scanning penetrates the surface to visualize thin optical sections to obtain 3-dimensional analysis of Mozzarella microstructure without disturbing the internal structure and to measure the size and shape of intact fat globules (Auty et al., 2001). Some evidence indicates that refrigerated storage of Mozzarella cheese caused swelling of the protein matrix and increases in size, area, and perimeter of the fat particles (McMahon et al., 1999; Joshi et al., 2004).

Confocal laser scanning microscopy was hence used in this study to help relate Mozzarella processing conditions to the microstructure and therefore to the final product quality. The relevant results of the analysis are reported in Figure 7.

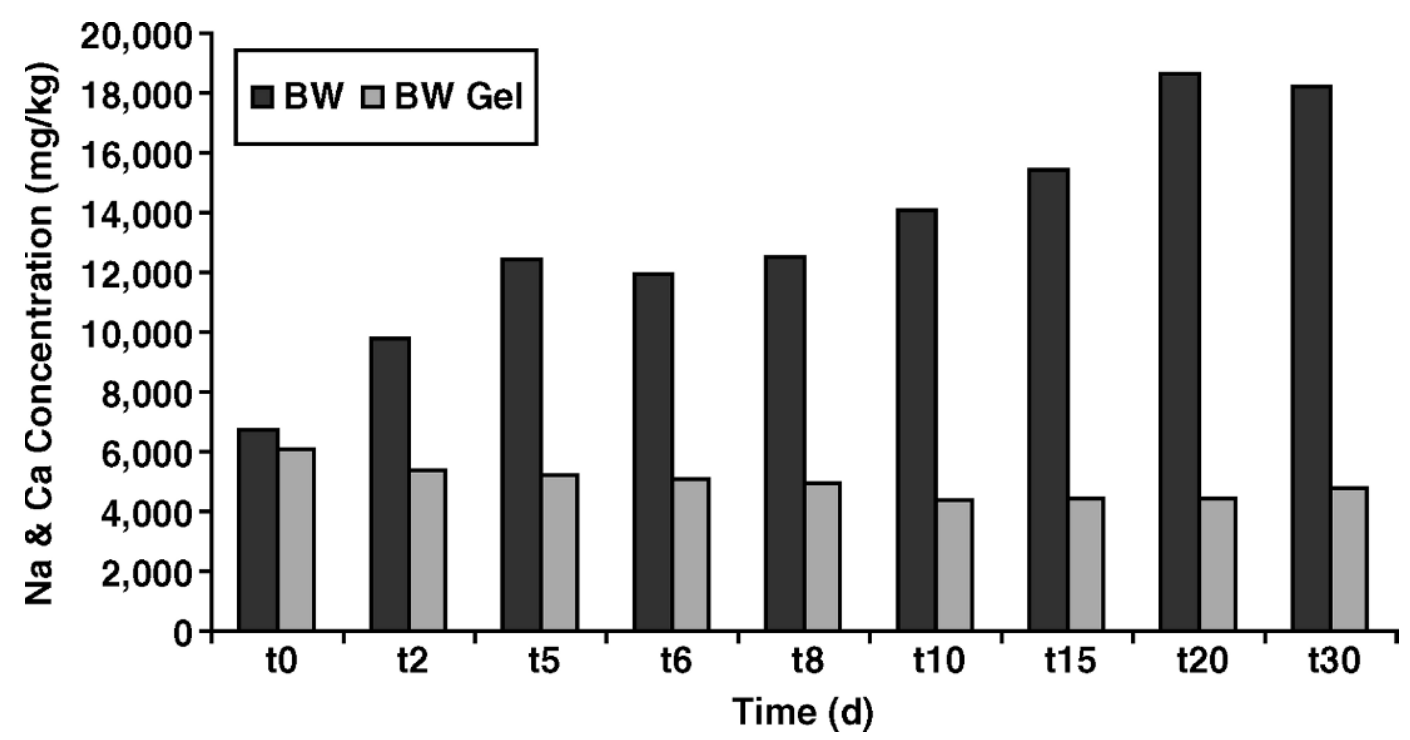

Figure 5. Sodium concentration in water buffalo cheese in preservation liquid and in gel (mg/kg) relative to conservation days. Standard deviation is less than $0.2 \%$. 


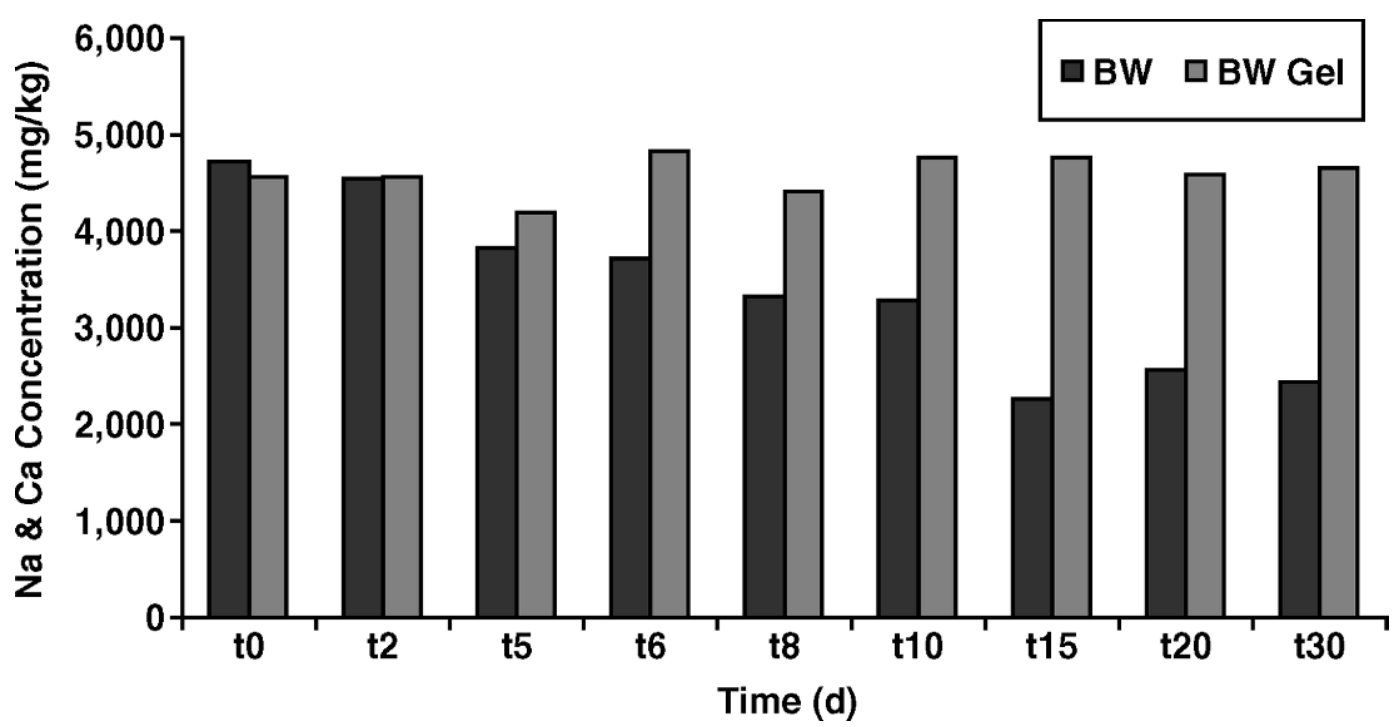

Figure 6. Calcium concentration in water buffalo cheese in preservation liquid and in gel ( $\mathrm{mg} / \mathrm{kg}$ ) relative to conservation days. Standard deviation is less than $0.2 \%$.

The storage of Mozzarella for $21 \mathrm{~d}$ without gel (Figure 7C) caused an alteration of the microscopic structure of Mozzarella, in particular of the protein network. In fact, the microstructure of the said Mozzarella, compared with the Mozzarella preserved in gel (Figure 7B), indicated that during storage in liquid, there was loss of identity of the protein fibers and swelling of the protein matrix. Also, the fat globules were generally bigger. Importantly, the protein fibers and fat globule microstructure of the Mozzarella after $21 \mathrm{~d}$ in gel were similar to that of the fresh Mozzarella (Figure 7A).

Table 2. Weight measurements of Mozzarella water buffalo cheese in preservation liquid and in gel at different times

\begin{tabular}{|c|c|c|c|c|}
\hline \multirow[b]{2}{*}{ Samples } & \multicolumn{2}{|c|}{ Weight (g) } & \multirow{2}{*}{$\begin{array}{l}\text { Difference } \\
(\mathrm{g})\end{array}$} & \multirow{2}{*}{$\begin{array}{c}\text { Difference } \\
(\%)\end{array}$} \\
\hline & Time $0(\mathrm{~d})$ & Time $2(\mathrm{~d})$ & & \\
\hline $\mathrm{WBLP}^{1}$ & 54.64 & 71.57 & +16.93 & +30.98 \\
\hline \multirow[t]{2}{*}{ WBgel $^{2}$} & 55.26 & 55.44 & +0.18 & +0.32 \\
\hline & & Time $4(\mathrm{~d})$ & & \\
\hline WBLP & 51.14 & 68.66 & +17.52 & +34.26 \\
\hline \multirow[t]{2}{*}{ WBgel } & 58.65 & 59.42 & +0.77 & +1.31 \\
\hline & & Time $6(\mathrm{~d})$ & & \\
\hline WBLP & 55.05 & 70.58 & +15.69 & +28.50 \\
\hline \multirow[t]{2}{*}{ WBgel } & 53.86 & 54.82 & +0.96 & +1.78 \\
\hline & & Time $8(\mathrm{~d})$ & & \\
\hline WBLP & 55.36 & 66.13 & +10.77 & +19.45 \\
\hline \multirow[t]{2}{*}{ WBgel } & 52.46 & 52.76 & +0.3 & +0.57 \\
\hline & & Time $10(\mathrm{~d})$ & & \\
\hline WBLP & 53.05 & 71.95 & +18.9 & +35.62 \\
\hline \multirow[t]{2}{*}{ WBgel } & 51.86 & 52.78 & +0.92 & +1.77 \\
\hline & & Time $15(\mathrm{~d})$ & & \\
\hline WBLP & 54.38 & 68.90 & +14.52 & +26.70 \\
\hline WBgel & 51.36 & 52.00 & +0.64 & +1.25 \\
\hline
\end{tabular}

${ }^{1} \mathrm{WBLP}=$ water buffalo Mozzarella cheese in preservation liquid.

${ }^{2} \mathrm{WBgel}=$ water buffalo Mozzarella cheese in gel. 

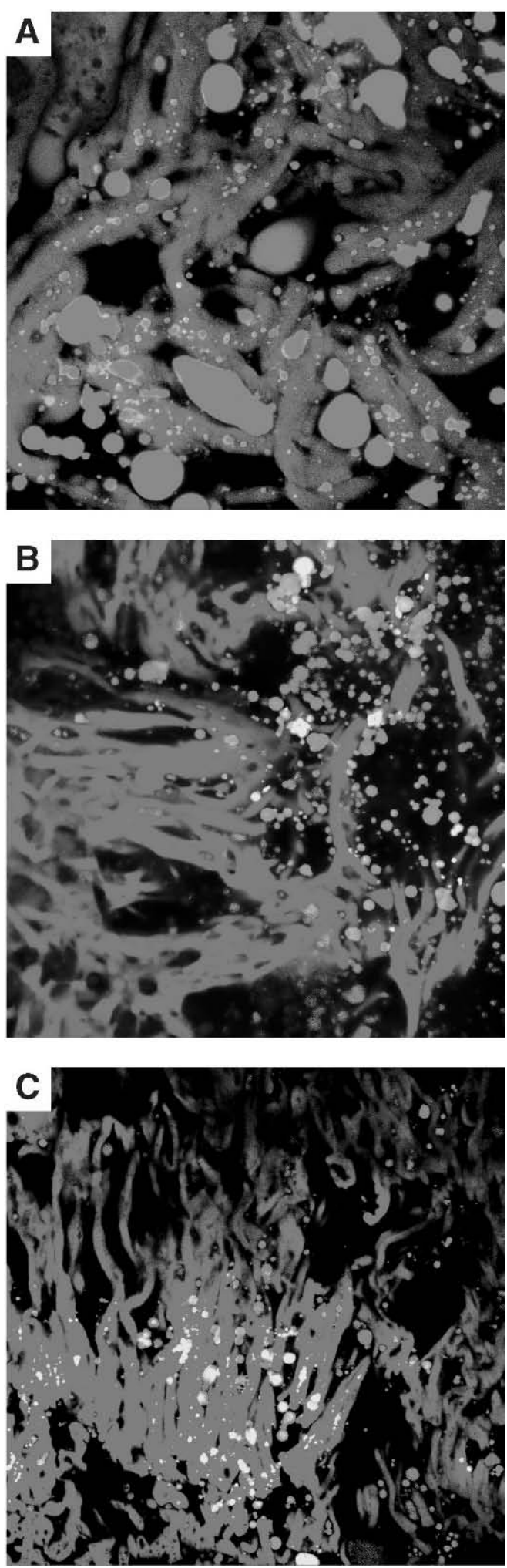

Figure 7. (A) Confocal fluorescence staining of Mozzarella after $21 \mathrm{~d}$ of storage in liquid, (B) Mozzarella after $21 \mathrm{~d}$ of storage in gel, and (C) fresh Mozzarella. (A) Alteration of the microscopic structure of protein fibers and fat globules is evident compared with (B) and (C). Color figure available online (http://jds.fass.org/content/vol91/issue4/)

\section{CONCLUSIONS}

The aim of this work was to explain the ability of an innovative packaging system based on natural gel to delay the loss of nutritional properties of WBM cheese until $30 \mathrm{~d}$, compared with WBM cheese in its preservation liquid as reported in a previous paper (Laurienzo et al., 2006).

We concentrated our investigation on measurements of salts and $\mathrm{pH}$; in fact a correlation between $\mathrm{pH}$, content in $\mathrm{Ca}, \mathrm{Na}$ content, and structure of Mozzarella cheese has been reported in the literature (Kimura et al., 1992; Kindstedt et al., 2001; Feeney et al., 2002).

Results obtained have confirmed the ability of the polysaccharide gel to avoid drastic change in the content of $\mathrm{Ca}$ and $\mathrm{Na}$ and in the values of $\mathrm{pH}$ that normally occur in liquid-stored Mozzarella cheese within $2 \mathrm{~d}$ of production. Strongly reduced changes in both parameters confirm their correlation with the preservation of the mechanical parameters (texture, stretchability, and flowability) in gel, as previously reported. Confocal laser scanning microscopy gave direct evidence of the persistence of physical structure of proteins and lipids in the gel-stored samples.

We can conclude that polysaccharide gel represents an efficient primary packaging to maintain for a prolonged time those parameters that have an effect on the shelf life of Mozzarella cheese.

\section{ACKNOWLEDGMENTS}

We are very grateful C. Meccariello (ISA, Consiglio Nazionale delle Ricerche) for technical support.

\section{REFERENCES}

Abd El-Salam, M. H., L. B. A. El-Hamid, R. A. Awad, A. M. Kholif, S. M. Abdou, M. Zedan, M. S. Wafaa, and S. El-Shibiny. 2004. Improving functional properties and texture of buffalo Mozzarella cheese using calcium chelating. 9th Egypt. Conf. Dairy Sci. Technol., Cairo, Egypt. Egypt. Soc. Dairy Sci., Cairo, Egypt.

Auty, M. A. E., M. Twomey, T. P. Guinee, and D. M. Mulvihill. 2001. Development and application of confocal scanning laser microscopy methods for studying the distribution of fat and protein in selected dairy products. J. Dairy Res. 68:417-427.

Feeney, E. P., T. P. Guinee, and P. F. Fox. 2002. Effect of pH and calcium concentration on proteolysis on Mozzarella cheese. J. Dairy Sci. 85:1646-1654.

Guinee, T. P., E. P. Feeney, M. A. E. Auty, and P. F. Fox. 2002. Effect of $\mathrm{pH}$ and calcium concentration on some textural and functional properties of Mozzarella cheese. J. Dairy Sci. 85:1655-1669.

Guo, M. R., J. A. Gilmore, P. S. Kindstedt. 1997. Effect of sodium chloride on the serum phase of Mozzarella cheese. J. Dairy Sci. 80:3092-3098.

Hassan, A., M. E. Johnson, and J. A. Lucey. 2004. Changes in the proportions of soluble and insoluble calcium during the ripening of Cheddar cheese. J. Dairy Sci. 87:854-862.

Joshi, N. S., K. Muthukumarappan, and R. I. Dave. 2004. Effect of calcium on microstructure and meltability of part skim Mozzarella cheese. J. Dairy Sci. 87:1975-1985. 
Kimura, T., Y. Sagara, M. Fukushima, and S. Taneya. 1992. Effect of $\mathrm{pH}$ on the submicroscopic structure of string cheese. Milchwissenschaft 47:547-552.

Kindstedt, P. S., A. M. Zielinski, and A. Almena-Aliste. 2001. A postmanufactured method to evalue the effect of $\mathrm{pH}$ on Mozzarella cheese characteristics. Aust. J. Dairy Technol. 56:202-207.

Laurienzo, P., M. Malinconico, R. Pizzano, C. Manzo, N. Piciocchi, A. Sorrentino, and M. G. Volpe. 2006. Natural polysaccharidebased gels for dairy food preservation. J. Dairy Sci. 89:2856-2864.

Lee, M. R., M. E. Johnson, and J. A. Lucey. 2005. Impact of modifications in acid development on the insoluble calcium content and rheological properties of Cheddar cheese. J. Dairy Sci. 88:3798-3809.

Lucey, J. A., M. E. Johnson, and D. S. Horne. 2003. Invited review: Perspectives on the basis of the rheology and texture properties of cheese. J. Dairy Sci. 86:2725-2743.

Malinconico, M., and M. G. Volpe. 2004. Packing systems for the conservation of fresh milk products, as mozzarella cheese or mozzarella-like cheeses (WO/2006/067825), CNR, Italy.
McMahon, D. J., R. L. Fife, and C. J. Oberg. 1999. Water partitioning in Mozzarella cheese and its relationship to cheese meltability. J. Dairy Sci. 82:1361-1369.

McMahon, D. J., B. Paulson, and C. J. Oberg. 2005. Influence of calcium, $\mathrm{pH}$, and moisture on protein matrix structure and functionality in direct-acidified nonfat Mozzarella cheese. J. Dairy Sci. 88:3754-3763.

Paonessa, A. 2004. Influence of the preservation liquid of Mozzarella di Bufala Campana D.O.P. on some aspects of its preservation. Bubalus Bubalis IV:30-36.

Pastorino, A. J., C. L. Hansen, and D. J. McMahon. 2003. Effect of salt on structure-function relationships of cheese. J. Dairy Sci. $86: 60-69$

Sood, V. K., D. K. Gaind, and R. K. Dewan. 1979. Correlation between micelle salvation and calcium content. N. Z. J. Dairy Sci. Technol $14: 32-34$.

Vitagliano, M. 1976. Il formaggio. Pages 515-541 in Industrie Agrarie. UTET, Turin, Italy. 